Open Access

\title{
Colon and Breast Anti-cancer Effects of Peptide Hydrolysates Derived from Rice Bran
}

\author{
Arvind Kannan ${ }^{1}$, Navam Hettiarachchy ${ }^{1, *}$ and Satya Narayan ${ }^{2}$ \\ ${ }^{I}$ Department of Food Science, University of Arkansas, Fayetteville, Arkansas \\ ${ }^{2}$ Department of Anatomy and Cell Biology and UF Shands Cancer Center, University of Florida, Gainesville, Florida
}

\begin{abstract}
Rice bran is an economical, under-utilized co-product of rough rice milling. The objective of this study was to produce rice-bran peptides and investigate for anti-cancer activity. Protein hydrolysates were prepared by treating heat stabilized defatted rice-bran with food grade Alcalase enzyme, followed by treatment with simulated gastric and intestinal juices to obtain resistant peptides. Resistant peptides were fractionated into $>50,10-50,5-10$, and $<5 \mathrm{kDa}$ sizes, freeze dried, and evaluated for inhibitory and cytotoxicity activities on human colon (HCT-116) and breast (HTB-26) cancer cell lines. The results showed that $<5 \mathrm{kDa}$ fraction of rice-bran is a potent anti-cancer agent. The cytotoxicity of the fraction to both cancer cell types was more pronounced after the treatment with $500 \mu \mathrm{g} / \mathrm{mL}$. The $\mathrm{IC}_{50}$ of the peptide fraction was approximately $750 \mu \mathrm{g} / \mathrm{mL}$. These results indicate that the $<5 \mathrm{kDa}$ peptide fraction separated from rice bran protein hydrolysate has a potent anti-tumor activity for colon cancer cells. The peptide fractions that demonstrate anti-cancer activities have the potential for use as functional food ingredients for health benefits.
\end{abstract}

\section{INTRODUCTION}

Colorectal and breast cancers are the leading causes of cancer related deaths and illnesses in the United States. According to the American Cancer Society, 49,960 estimated deaths for colon cancer (both sexes) and 40,480 estimated deaths for breast cancer (females) were reported in the year 2008 indicating not much reduction in the incidence or mortality rates compared to projected estimates in previous years [1]. With dietary and environmental factors playing critical roles in the cause and progression of these cancers [2], it is necessary to explore natural alternatives that are inexpensive and can be available in bulk.

Naturally available foods and their components may have the ability to serve as modulators of anti-tumorigenicity either as separate entities or act in synergism [3]. Identification of such compounds within naturally available foods or co-products obtained during the processing of unprocessed foods has promoted nutraceuticals as inexpensive alternatives to expensive therapeutic modalities, especially reducing the risks on those genetically predisposed. Furthermore, the combination of two or more compounds in drug design has proved clinically synergistic benefits toward the treatment strategies for cancer [4]. These could serve to modify the dietary determinants and hence slow down the progression of cancers.

Bioactive compounds, those that bear nutraceutical action, encompass a wide range of functional groups present within foods that are able to affect biological function. They comprise mostly the aromatic alcohols like polyphenols, and acidic (phenolic acids) compounds and have been shown to

*Address correspondence to this author at the Department of Food Science, University of Arkansas; E-mail: nhettiar@uark.edu contribute to mitigate disease pathology in cardiovascular disease and cancer [5]. In order for these compounds to impart specific bioactivities it is necessary that they be released or extracted from the parent food source, be resistive to degradation by gut enzymes/microbes, and be pure from other interacting substances. Proteins and peptides also are listed as bioactive compounds able to and already documented as imparting several physiological functions including antioxidant, anti-obesity, anti-angiogenic, antihypertensive, hypocholesterolemic and immunomodulatory [6-11]. Several protein-rich sources including cereal grains and their constituents like proteins and peptides that can bear potential bioactivities have been documented [12]. Most of the protein isolates and hydrolysates are commonly being prepared from protein-rich sources like soy and whey. Our aim was to utilize a naturally rich co-product obtained during the processing of rice. There have been relatively few studies that have focused on determining bioactive properties of rice and its components [13]. To stress, constituents like proteins and peptides from rice or co-products of rice-milling such as the bran have not been evaluated for properties that may serve to reduce disease symptoms or propensities even with evidences of peptides and protein hydrolysates from cereals tending to possess anti-disease characteristics. Hence, we aimed at investigating peptide hydrolysates derived from rice-bran, a co-product of rough rice-milling for a possible inhibitory activity against human colon and breast cancer cells.

Rice-bran is a cheap co-product of rough rice-milling having nutrients including $\mathrm{B}$ vitamins, minerals and fiber [14]. It is being used as a low-cost animal feed and is produced in abundant quantities in the State of Arkansas. In previous studies, it has been shown that whole rice-bran extracts possess anti-proliferative, anti-mutagenic as well as anti-oxidative properties [13]. Our research has shown 
that gastrointestinal resistant bran peptide fractions show promising activities against colon and liver cancer cell viability and proliferation in vitro [15]. Such studies on identifying specific components that could possibly contribute to anti-disease characteristics within rice-bran protein isolates or peptides are very minimal and have motivated research in this area and to also examine other cancer cell lines for activity. Thus, the objectives of our study were to prepare peptide hydrolysates from rice-bran using a foodgrade proteolytic enzyme, conduct gastrointestinal (GI) treatment to the hydrolysates, fractionate the GI-resistant peptide hydrolysates into $>50,50-10,5-10 \mathrm{kDa}$, and $<5 \mathrm{kDa}$ fractions and investigate bioactivity against colon and breast cancer cells in vitro.

\section{MATERIALS AND METHODOLOGY}

\section{Rice-Bran}

We obtained the heat stabilized de-fatted rice-bran (HDRB) from Riceland foods (Stuttgart, AR), the Romicon ultrafiltration system was purchased from Koch membrane systems (Massachusetts, USA), and the food-grade Alcalase enzyme derived from a bacterial strain purchased from Novozyme (North Carolina, USA).

\section{Cell Lines}

Human colon (HCT-116) cancer and breast (HTB-26) cancer cell lines were purchased from ATCC (Manassas, Virginia, USA), Dulbecco's modified Eagle's medium, fetal bovine serum, gentamycin, penicillin, and streptomycin were purchased from Hyclone (Logan, UT, USA). MTT kit and McCoy's SA medium were purchased from ATCC (Manassas, Virginia, USA). All other chemicals were purchased from Sigma-Aldrich Chem. Co. (St. Louis, MO, USA).

\section{Direct Hydrolysis of HDRB to Obtain Protein Hydrolysates}

Approximately $500 \mathrm{~g}$ of ground and sieved HDRB (passed through 60 mesh) were homogenized with $0.6 \mathrm{~L}$ deionized water and stirred for $30 \mathrm{~min}$ at room temperature. Based on a response surface method optimization design, HDRB was digested with 3.5 AU (Anson units of enzyme) Alcalase $(4970 \mu \mathrm{L})$ at $\mathrm{pH} 8.0$ and heated at $50^{\circ} \mathrm{C}$ for $60 \mathrm{~min}$ [15]. After this, the enzyme was inactivated by heating at $85^{\circ} \mathrm{C}$ for $3 \mathrm{~min}$ [16]. The hydrolysis mixture was centrifuged at $3,000 \mathrm{~g}$ for $15 \mathrm{~min}$ to obtain the hydrolysates in the supernatant. The supernatant was freeze-dried and stored at $4{ }^{\circ} \mathrm{C}$ until needed.

\section{Generating Gastrointestinal (GI) Juices Resistant Bran Hydrolysates}

It is essential that the peptides be resistant to the GI tract to impart uninhibited biological function and bioavailability. Hence the bran hydrolysates were passed through a simulated gastric and intestinal solution as previously described in [15].

\section{Fractionation of GI-resistant Bran Peptide Hydrolysates by Ultrafiltration}

Fractionation using the ultrafiltration equipment was carried out for the GI-resistant bran protein hydrolysates with a Romicon ultrafiltration system equipped with 1 " diameter hollow-fiber polysulfone membrane cartridges. Approximately $500 \mathrm{~mL}$ of filtered soluble GI-resistant peptide hydrolysates were run through sequential ultrafiltration columns with membrane-cartridges having nominal molecular weight cut-offs (MWCO) of 50, 10, and $5 \mathrm{kDa}$. Approximately one third of the volume of the hydrolysate was ultrafiltered through each membrane as retentates and the rest as permeates, as previously described [15]. Approximately 200mL of fractions were obtained. The fractions were freeze-dried and stored at $4^{\circ} \mathrm{C}$. The GI-resistant bran fraction $<5 \mathrm{kDa}$ was tested for inhibitory activity against human colon (HCT-116) and breast (HTB-26) cancer cell lines.

\section{Human Colon (HCT-116) and Breast (HTB-26) Cancer Cell Culture}

Human colon cancer cell line HCT-116 was grown in McCoy's 5a medium supplemented with $10 \%$ fetal bovine serum (FBS; HyClone, Logan UT) and $100 \mu \mathrm{g} / \mathrm{mL}$ of penicillin and streptomycin (GIBCO-BRL). Human breast (HTB26) cancer cell line was cultured separately at $37^{\circ} \mathrm{C}$ in DMEM (Dulbecco's Modified Eagles Medium) in the presence of $10 \%$ fetal bovine serum, supplemented with $1 \mathrm{mM}$ L-glutamine, sodium pyruvate, $1 \mathrm{mM}$ sodium bicarbonate and $50 \mu \mathrm{g} / \mathrm{mL}$ gentamycin. Cells were grown at $37^{\circ} \mathrm{C}$ under a humidified atmosphere of 5\% carbon dioxide. Earlier work [15] designated $<5 \mathrm{kDa}$ peptide fraction to be best in inhibiting growth of cancer cells. Hence $<5 \mathrm{kDa}$ was selected for testing against HCT-116 and HTB-26 cell lines. After cell growth achieved $70 \%$, they were treated with different concentrations of bran peptide fraction $<5 \mathrm{kDa}$ for different time periods and evaluated for growth inhibition properties.

\section{MTT Assay}

To determine the effect of rice-bran peptide fraction on the inhibition of cell proliferation, we performed [3-(4,5dimethyl thiazole-2-yl)]-2,5-diphenyl tetrazolium bromide (MTT)-based cell titer assay. A single cell suspension (1,000 cells) was placed in 96-well plates. The cells were allowed to attach and grow for $36 \mathrm{~h}$. After that the old medium was replaced with fresh medium and samples of rice-bran peptide $<5 \mathrm{kDa}$ fractions were added into the wells for determining the effect on growth as a concentration- and time-dependent manner. MTT dye was added after each time-point followed by the termination of the formation of colored formazan product by a detergent solution. The plate was read at 570 $\mathrm{nm}$ in a Tunable Versamax Microplate Reader (Molecular Devices, Sunnyvale, CA). For control, appropriate row or column of wells was left untreated at each time-point.

\section{Clonogenic Assay}

To determine the anti-cancer activity of rice-bran peptides, we performed the clonogenic cytotoxicity assay. Clonogenic assay is a frequently used cancer research assay that tests the efficacy of compounds on proliferating cancer cells [17]. The clonogenic assay was performed using the HCT-116 cell line following a published procedure [18]. Cells were trypsinized and a single cell suspension was prepared. Cells were plated at a density of 100 cells per $35 \mathrm{~mm}$ well. Cells were treated with different concentrations of the rice-bran peptide fraction. After $72 \mathrm{~h}$, the medium was replaced with fresh medium. Cells were allowed to grow for another 8 days and then stained with $0.025 \%$ crystal violet. 
The excess crystal violet was removed with $30 \%$ methanol, plates were air dried at room temperature, and numbers of colonies were counted.

\section{Data Analysis}

Experimental data were analyzed using SigmaPlot statistical software (Systat Software, Inc., San Jose, CA) with sample means and standard errors of approximately $10 \%$.

\section{RESULTS}

\section{Enzymatic Hydrolysis of Rice-Bran by Alcalase Enzyme and Protein Contents}

The parameters for enzymatic hydrolysis [Alcalase concentrations $(0.5,3.5$ and 10 Anson units), $\mathrm{pHs}(6,8,10)$, temperatures $\left(40^{\circ} \mathrm{C}, 50^{\circ} \mathrm{C}, 60^{\circ} \mathrm{C}\right)$ and incubation times for digestion (30 min, $60 \mathrm{~min}, 90 \mathrm{~min}$ )] were previously used and optimized using RSM to obtain optimum peptide hydrolysates from HDRB [15]. The prediction profile designated 3.5 AU enzyme concentration, $\mathrm{pH} 8,50^{\circ} \mathrm{C}$ temperature, and a 60 min digestion time was considered optimal for obtaining the degree of hydrolysis (OPA method) at around 25\%.

\section{Inhibitory Activity of Rice-Bran <5 kDa Fraction}

Treatment with rice-bran $<5 \mathrm{kDa}$ fraction at 24 and $48 \mathrm{~h}$ time-points revealed no inhibition in the growth of HCT-116 colon cancer cells compared to the untreated cells, whereas at the $72 \mathrm{~h}$ time-point there was a dose- and time-dependent inhibition in the growth of HCT-116 cells (Fig. 1). The growth of HCT-116 cells was reduced by nearly $80 \%$ after the treatment with $650 \mu \mathrm{g} / \mathrm{mL}$ of the $<5 \mathrm{kDa}$ fraction at the $72 \mathrm{~h}$ time-point. Similar results were obtained with HTB-26 breast cancer cells. Treatment with rice-bran $<5 \mathrm{kDa}$ fraction at 24 and 48 time-points showed no inhibition compared to the untreated cells. However, at the $72 \mathrm{~h}$ time-point there was a significant inhibition in the growth of HTB-26 cells in a dose- and time-dependent manner (Fig. 2). Like HCT-116 cells, the HTB-26 cells also showed maximum sensitivity at $650 \mu \mathrm{g} / \mathrm{mL}$ of $<5 \mathrm{kDa}$ fraction treatment with a $65 \%$ inhibition in the growth at $72 \mathrm{~h}$ time-point. Earlier studies, with $>50,10-50$ and 5-10 $\mathrm{kDa}$ fractions revealed no growth inhibitory effect on colon and liver cancer cells [15]. However, the present study indicates that the growth inhibitory activity for colon and breast cancer cells of rice-bran peptide is present in the $<5 \mathrm{kDa}$ fraction.

The clonogenic assay also indicates the toxicity of the $<5$ kDa fraction to HCT-116 cells (Fig. 3). The cytotoxicity of the $<5 \mathrm{kDa}$ fraction was pronounced after treating the cells with $500 \mu \mathrm{g} / \mathrm{mL}$ and that the $\mathrm{IC}_{50}$ dose of the $<5 \mathrm{kDa}$ fraction was $770 \mu \mathrm{g} / \mathrm{mL}$. These results indicate that $<5 \mathrm{kDa}$ peptide fraction of the rice-bran has a potent anti-tumor activity for

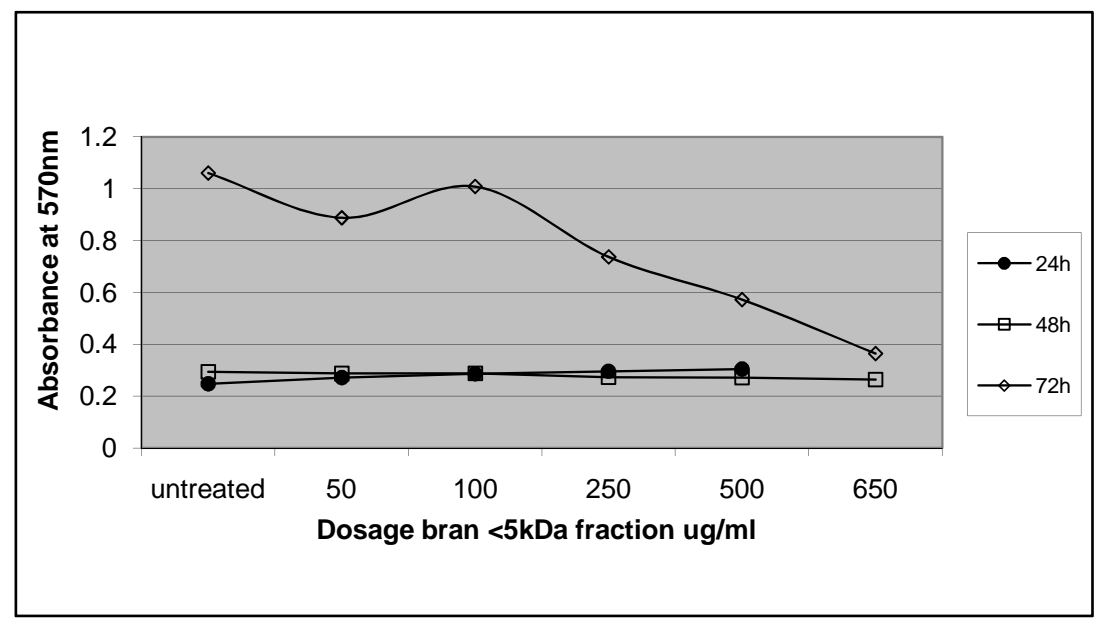

Fig. (1). MTT assay for the determination of the anti-proliferative activity of bran peptide $<5 \mathrm{kDa}$ fraction with HCT-116 cells.

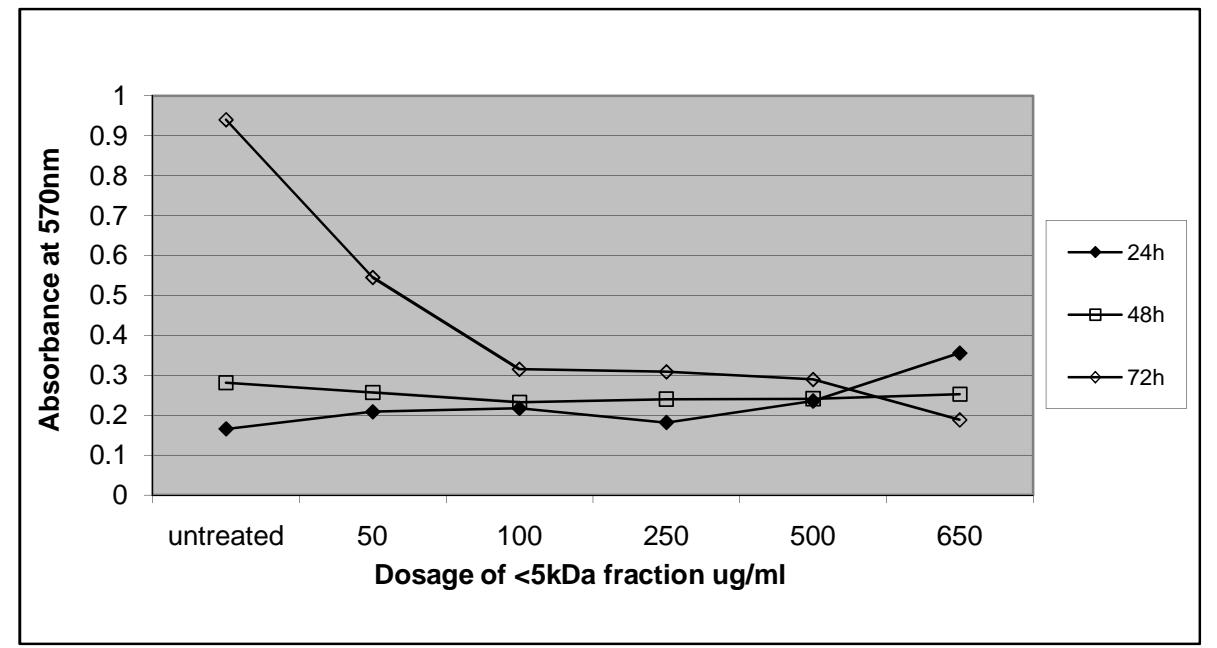

Fig. (2). MTT assay for the determination of the anti-proliferative activity of bran peptide $<5 \mathrm{kDa}$ fraction with HTB-26 cell. 
colon cancer cells.

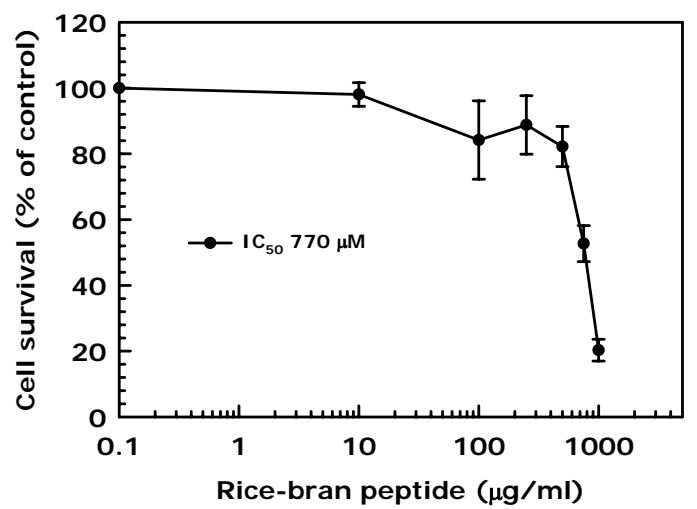

Fig. (3). Clonogenic toxicity assay for bran peptide $<5 \mathrm{kDa}$ fraction with HCT-116 cells.

\section{DISCUSSION AND CONCLUSION}

For obtaining peptides from cereal proteins enzymatic approach [15] is preferred over chemical method where extraction by enzymatic hydrolysis yielded substantial amounts of protein when preparing protein isolates [19]; however, combination of several parameters for a substrate contribute to different types of biological activities [20]. In this study and as observed in our earlier study [15] HDRB was digested with food-grade proteolytic enzyme (Alcalase) to obtain peptide hydrolysates.

The initial screening for determination of anti-cancer activity was done employing the MTT assay and subesequently confirmed by clonogenic assay on the promising anti-cancer fraction. The time- and concentration-dependent growth inhibition patterns observed with the $<5 \mathrm{kDa}$ peptide fraction on HCT-116 and HTB-26 reveal better results with HCT-116 cells by the MTT assay. This suggests that the fraction could have a better and positive impact on reducing progression of human colon cancer. Further, the clonogenic assay, which also reflects cytotoxicity confirms that a higher dosage and longer time is needed for the $<5 \mathrm{kDa}$ fraction to have strong inhibitory or cytotoxicity effect on the growth of especially the colon cancer cells. Since $<5 \mathrm{kDa}$ fraction showed a better inhibition on colon cancer cells compared to liver cancer cells, clonogenic assay of the $<5 \mathrm{kDa}$ fraction was done only on colon cancer cells. The dosage and timedependent growth inhibition pattern may imply that the fractions may be a slow-acting. Higher doses may reduce the time needed for killing the maximum number of cells. Amino acid make-up and the purity of these fractions can determine the extent of inhibitory activity. Isolation and purification of $<5 \mathrm{kDa}$ fraction peptide(s) that show similar or enhanced extent of anti-cancer activity may form the basis for fully characterizing the anti-cancer bran peptide.

\section{REFERENCES}

[1] American Cancer Society. Cancer Facts and Figures 2008. http://www.cancer.org/downloads/STT/2008CAFFfinalsecured.pdf (Accessed Nov 2008)
[2] Anand, P.; Kunnumakkara, A.B.; Sundaram, C.; Harikumar, K.B.; Tharakan, S.T.; Lai, O.S.; Sung, B.; Aggarwal, B.B. Cancer is a preventable disease that requires major lifestyle changes. Pharm. Res., 2008, 25(9), 2097-116.

[3] Hemaiswarya, S.; Doble, M. Potential synergism of natural products in the treatment of cancer. Phytother. Res., 2006, 20(4), 239-49. Review.

[4] Lao, C.D.; Brenner, D.E. Strategies for prevention of colorectal cancer: pharmaceutical and nutritional interventions. Curr. Treat. Options Oncol., 2004, 5(5), 417-26. Review.

[5] Kris-Etherton, P.M.; Hecker, K.D.; Bonanome, A.; Coval, S.M.; Binkoski, A.E.; Hilpert, K.F.; Griel, A.E.; Etherton, T.D. Bioactive compounds in foods: their role in the prevention of cardiovascular disease and cancer. Am. J. Med. 2002, 30(113), 71S-88S.

[6] Li, S.Q.; Zhang, Q.H. Advances in the development of functional foods from buckwheat. Crit. Rev. Food Sci. Nutr., 2001, 41, 45164, 2001.

[7] Parkash, A.; Ng, T.B.; Tso, W.W. Purification and characterization of charantin, a napin-like ribosome-inactivating peptide from bitter gourd (Momordica charantia) seeds. J. Pept. Res., 2002, 59, 197202.

[8] Gauthier, S.F.; Pouliot, Y. Functional and biological properties of peptides obtained by enzymatic hydrolysis of whey proteins. $J$. Dairy Sci., 2003, 86, E78-87.

[9] Algaron, F.; Miranda, G.; Le Bars, D.; Monnet, V. Milk fermentation by Lactococcus lactis with modified proteolytic systems to accumulate potentially bioactive peptides. Lait, 2004, 84, 115-23.

[10] Murakami, M.; Tonouchi, H.; Takahashi, R.; Kitazawa, H.; Kawai, Y.; Negishi, H.; Saito, T. Structural analysis of a new antihypertensive peptide ( $\beta$-Lactosin B) isolated from a commercial whey product. J. Dairy Sci., 2004, 87, 1967-74.

[11] Quiros, A.; Hernandez-Ledesma, B.; Ramos, M.; Amigo, L.; Recio, I. Angiotensin-converting enzyme inhibitory activity of peptides derived from caprine kefir. J. Dairy Sci., 2005, 88, 3480-7.

[12] Mine, Y.; Shahidi, F. Nutrient Absorption System In: Nutraceutical Proteins and Peptides in Health and Disease; CRC press: USA, 2006.

[13] Nam, S.H.; Choi, S.P.; Kang, M.Y.; Kozukue, N.; Friedman, M. Antioxidative, antimutagenic, and anticarcinogenic activities of rice-bran extracts in chemical and cell assays. J. Agric. Food Chem., 2005, 53, 816-22.

[14] Juliano, B.O. Rice-Bran. In: Rice: Chemistry and Technology; Juliano, B.O. Ed.; American Association of Cereal Chemists: St. Paul, MN, USA, 1985, p. 647.

[15] Kannan, A.; Hettiarachchy, N.S.; Johnson, G.M.; Nannapaneni, R. Human colon and liver cancer cell proliferation inhibition by peptide hydrolysates derived from heat-stabilized defatted rice bran. J. Agric. Food Chem., 2008, JF802558V, Accepted November 10, 2008.

[16] Anonymous. Alcalase Food Grade B 318b-GB 2000; Novo Industri A/S: Bagsvaerd, Denmark, 1988.

[17] Hoffman, R.M. In vitro sensitivity assays in cancer: a review, analysis, and prognosis. J. Clin. Lab. Anal., 1991, 5, 133-43.

[18] Balusu, R.; Jaiswal, A.S.; Armas, M.L.; Kundu, C.N.; Bloom, L.B.; Narayan, S. Structure/function analysis of the interaction of adenomatous polyposis coli with DNA polymerase beta and its implications for base excision repair. Biochemistry, 2007, 46(49),1396174 .

[19] Tang, S.; Hettiarachchy, N.S.; Shelhammer, T.H. Protein extraction from heat stabilized defatted rice bran. 1. Physical processing and enzyme treatments. J. Agric. Food Chem., 2002, 50, 7444-8.

[20] Wang, W.; Gonzalez de Mejia, E. A new frontier in soy bioactive peptides that may prevent age-related chronic diseases. Comp. Rev. Food Sci. Food Saf. Inst. Food Technol., 2005, 4, 63-78. 